\title{
Artelogie
}

Recherche sur les arts, le patrimoine et la littérature de l'Amérique latine

15 | 2020

Latin American networks: Synchronicities, Contacts and Divergences.

\section{A Conceptual Definition of the Artist's Book and A New Look at Ulises Carrión's Thinking}

\section{Paulo Silveira}

Translator. Andrea Giunta/Jane Brodie

\section{OpenEdition}

\section{Journals}

Electronic version

URL: http://journals.openedition.org/artelogie/4411

DOI: 10.4000/artelogie.4411

ISSN: 2115-6395

Publisher

Association ESCAL

Electronic reference

Paulo Silveira, «A Conceptual Definition of the Artist's Book and A New Look at Ulises Carrión's

Thinking », Artelogie [Online], 15 | 2020, Online since 08 April 2020, connection on 06 August 2020

URL : http://journals.openedition.org/artelogie/4411

This text was automatically generated on 6 August 2020.

Association ESCAL 


\title{
A Conceptual Definition of the Artist's Book and A New Look at Ulises Carrión's Thinking
}

\author{
Paulo Silveira \\ Translation : Andrea Giunta/Jane Brodie
}

Traslated by Andrea Giunta

Copyedited by Jane Brodie

\section{Introduction}

1 This article emphasizes the importance of Ulises Carrion's thinking and activities to an art history that recognizes and privileges international experiences, specifically the relationship between Latin American and North American identities and their occasional connections with Europe. It addresses Carrión's production, mostly his work around publications conceived by artists, particularly artists' books. Bibliomorphic artistic production-of which the book is the paradigmatic form-is understood as an instrumental component of cultural strategies.

2 The legacy of Mexican artist Ulises Carrión's production has received a great deal of attention on art circuits, whether those circuits revolve around artistic practices or the study of art. His legacy is particularly pertinent because of its influence on both European and Pan-American contexts. It reveals links that have united artists from different continents, as well as the differences and similarities between those who remain in their countries of birth and those who move and find a place for themselves in new social structures. Carrión has gained recognition gradually in academic research as well. A number of methodologies have been used to grapple with his myriad practices. The researchers who have discovered (or rediscovered) Carrión's work can be divided into two main groups: the first are artists, most of them young, interested (and surprised) by the relationships between the current context and the historical conceptual network that took shape in the sixties; and the second are historians and 
theorists who work critically on information and contexts (artwork and its producers and consumers, as well as archives who live with collections). Each of these subjects has its own hypotheses and problems. Based on documentary sources, their research methods engage the work's approach (rules, discipline) and status (condition, quality). That is, these subjects address the work of art (with all the ambiguity that the aura, with its passion for the supreme, entails), as opposed to the document (with its bureaucratic and forensic meaning, its accessory character that leads it, often unfairly, to be stripped of aesthetic and artistic value). Editions published by artists-especially artists' books-are a structuring and functional feature of contemporary art and the new media. Because of their imponderable value and form, their language and function, these publications and related forms must be considered in their specificities, heeding at once their artistic nature and their communicability as well as, in an instrumental sense, their value as primary sources for research.

3 In this case study, I will provide a summary and a reassessment of Carrión's growing and-arguably-constructively impertinent, as well as intermittent, presence in research conducted since the mid-nineties at the Universidade Federal do Rio Grande do Sul, Brazil. ${ }^{1}$ The main aim of that research, which is ongoing, is to analyze the aesthetic and the rhetoric of the artist's book (understood as a category). While always interesting, that research encompasses branches of greater or lesser importance to the study of how new media and new languages took shape in the twentieth century; methodological issues in art research and art history; the formation of collections; the role of the university in contemporary art; editorial production in the arts; and writings by artists. From the formal beginning of my research, I understood that my point of view would be rooted in a local context to, from there, expand into regional, national, and international circles. Carrión's name came into my work in an ambiguous and seemingly-contradictory way: he was a constant point of reference in efforts to create unique or small print-run books (justified, paradoxically, by artisans and artists as a repudiation of conceptualism); and he was one of the protagonists in mail art to which Dick Higgins's concept of “intermidia" was key. ${ }^{2}$

4 The perspective of my research on Carrión is not national. Its aim is to salvage from oblivion links connected to the political commitment of Brazilian art in the seventies which was obscured by commercial interests during the eighties (the decade when the Brazilian art economy focused on "expressive"-and emphatically non-conceptualproduction). In relation to the network ${ }^{3}$ and what I call verb-visual discourses, Carrión and his influence was limited in the Portuguese-speaking Brazilian university context and in Latin America generally. ${ }^{4}$ In Brazil, the growth of graduate and postgraduate programs in art history are slowly giving Carrión and his legacy the academic recognition they deserve.

\section{Ulises Carrión}

Ulises Carrión Bogard was born in San Andrés Tuxtla, Mexico, in 1941, and died in Amsterdam, the Netherlands, in 1989, at the age of forty-eight (according to HELLION, 2003, and other sources). Whether an exile (as DEBROISE and MEDINA argue, 2014: p.23) or an expat, his life was characterized by mobility, starting with a study trip. Creative curiosity is what took him beyond Mexico. Europe was his home (it was from there that he visited North and South America), and the center of activities that joined together 
his many facets: Carrión was a writer and a visual artist, but also an entrepreneur in the art world, an advocate of the languages emerging in the seventies and eighties, especially those that involved word, image, and action (SILVEIRA, 2010,2011, 2012). He arrived in Amsterdam in 1970, and in 1972 he opened the In-Out Center-an exhibition venue in operation for three years-as well as a small press. In 1975, he and Aart van Barneveld founded Other Books and So, a space for the exhibition and sale of pioneering publications. It is considered the first bookstore for artists' publications anywhere in the world (HOFFBERG, 1979: p. 128). In-Out Center sold editions by a range of artists, many of them recognized figures in art history and others soon to join them. He had a large circle of friends in Amsterdam, and welcomed frequent guests from the city and beyond. Unfortunately, the bookstore closed in 1978. In 1980, its collection formed the basis for the Other Books and So Archive, open until the time of Carrión's death nine years later. In the absence of someone to replace him, his death interrupted the stream of information he set in motion.

6 At the beginning of the seventies Carrión declared to his friends his waning interest in traditional literature and his perception of the inadequacy as the linguistic instrument. ${ }^{5} \mathrm{He}$ considered the decisions that had led him to the visual arts inevitable. He knew that the Other Books and So archive was a business undertaking, both a real entity and a construct, a mental device no less spontaneous than intellectual, something innate to his theoretical convictions. According to his accounts, the archive, although it contained elements not primarily aesthetic, was in the end a work of art (see, in particular, CARRIÓN, 1980, and the video Bookworks Revisited. Part 1: A Selection, 1987). As a major work (mater work), as a set with rules and order, the archive might contain other works, thus reflecting its context as part of a broader structure: the visual arts were contained in culture, in a larger system. Carrión's generation was aware of the importance of experiments and curatorial projects of this type insofar as they confirmed temporality and discursiveness as fundamental to the visual arts. They might have economic potential (whether real or symbolic) if intimately linked to the domains of the artwork itself (the archive gives rise to poetic passion-indeed that is one of its most prominent side effects). The following years would see the opening of commercial spaces, some of them more alternative than others, that would confirm the principles underlying Other Books and So. Such spaces are complementary to the system, and some stand out in recent art history. They include Printed Matter (New York), Art Metropole (Toronto), Boekie Woekie (Amsterdam), Florence Loewy (Paris), and Bookartbookshop (London). Distribution of publications via post was also key to a certain conception of "cultural strategies" (CARRION, 1980: p. 51).

This radical shift [the focus from what is traditionally called "art" to the wider concept of "culture"] gives birth to quite a number of theoretical and practical questions, the most evident of them being, Where does the border lie between an artist's work and the actual organization and distribution of the work? As it usually happens, this question can only be answered by the artists themselves rather than by theoreticians, historians, and bureaucrats. When an artist is busy choosing his starting point, defining the limits of his scope, he has the right to include the organization and distribution of his work as an element of the same work. And by doing so, he's creating a strategy that will become a constituent formal element of the final work." (CARRION: 1980, p. 51) 


\section{Other books}

7 Carrión's texts are essential for those interested in books and publications as prime material for artistic expression and as support for the circulation of verbal-visual information. Although Carrion's written work is abundant (encompassing works of literature and plays), his texts on the visual arts are relatively few. Carrión gradually abandoned the conventional text and began using language in hybrid or unusual contexts. Nevertheless, he did write a number of essays of great interest. "The New Art of Making Books" is essential reading on the artist's book. It was published in Mexico City in early 1975 in Plural magazine, edited by Octavio Paz (1914-1998), and the same year in Kontexts, based in Amsterdam, thanks to which it circulated internationally. The article was later published in Second thoughts (1980), an anthology of a selection of Carrión's writings. ${ }^{6}$ The text's distribution grew when it was featured in Artists' Books: A Critical Anthology and Sourcebook (1985), edited by Joan Lyons. Pursuant to that edition, it was included in a number of international publications (exhibition catalogs, course brochures, internet sites, etc.). ${ }^{7}$

Let's take a look at Carrión's rhythmic prose in his original publication in Plural magazine in 1975:

El lenguaje del nuevo arte es radicalmente diferente del lenguaje cotidiano. Olvida intenciones y utilidad, y retorna a él mismo, se auto-investiga, buscando formas, series de formas que hagan nacer, asocien, revelen, las secuencias espacio-tiempo.

$\cdots$

Las palabras en un nuevo libro son las portadoras de un mensaje, ni las portavoces del alma, ni la moneda de la comunicación.

Aquellas fueron ya nombradas por Hamlet, una ávido lector de libros: palabras, palabras, palabras.

...

Las palabras del nuevo libro están allí no para trasmitir ciertas imágenes mentales con cierta intencionalidad.

Están allí para formar, junto a otros signos, una secuencia espacio-tiempo que nosotros identificamos con el nombre de "libro".

$\ldots$

Las palabras en un nuevo libro pueden ser las propias palabras del autor o las palabras del algún otro.

Un escritor del nuevo arte escribe muy poco o no escribe nada.

...

El libro más hermoso y el más perfecto del mundo en un libro con solo páginas en blanco, de la misma manera que el lenguaje más completo es aquel que se extiende más allá de las palabras que un hombre puede pronunciar.

In the English version of Second thoughts (1980: p. 15):

New art's language is radically different from daily language. It neglects intentions and utility, and it returns to itself, it investigates itself, looking for forms, for series of forms that give birth to, couple with, unfold into, space-time sequences.

.....

The words in a new book are not the bearers of the message, nor the mouthpieces of the soul, nor the currency of communication.

Those were already named by Hamlet, an avid reader of books: words, words, words.

.....

The words of the new book are there not to transmit certain mental images with a certain intention. 
They are there to form, together with other signs, a space-time sequence that we identify with the name 'book.'

.....

The words in a new book might be the author's own words or someone else's words. A writer of the new art writes very little or does not write at all.

......

The most beautiful and perfect book in the world is a book with only blank pages, in the same way that the most complete language is that which lies beyond all that the words a man can say.

"The New Art of Making Books" is in an imperative, direct voice. It is a series of postulates that affirms Carrión's conviction that the new book has emerged as an alternative space of expression. While it is true that in 1975 Carrión was not yet using the terms "artist's book," or-his favorite-"bookwork," expressions that would soon be enshrined, they do make themselves felt in the text. Carrión's reflections are seductive, and they inspired admiration in those beginning to study the book as artistic support. Insofar as the text is (or attempts to be) programmatic-a declarative and regulatory discursive construction-it is reminiscent of the manifestos issued by the modern avant-gardes. In that sense, it can be seen as outdated and alien to contemporary procedures, even though one of their most important heralds.

Less dogmatic is Bookworks Revisted, a text based on the presentations he made in the United States in November 1979 and November 1980. Carrión prepared the presentation first for "Options in Independent Art Publishing," a part of the Conference on Alternative Art Publishing held in the framework of the Visual Studies Workshop, Rochester, and second for the Art Institute of Boston (CARRION, 1980: p. 56 ). The text and presentations may well have been based on lectures with a similar theme he gave in Recife, Brazil in 1978 (at the Universidade Católica of Pernambuco ), in São Paulo (at the Pinacoteca do Estado), and in Buenos Aires, Argentina (at the Centro de Arte y Comunicación (CAYC)) (SCHRAENEN, 1992: p. 124), among other places. Everything would indicate that the images he showed at the lectures he delivered in the United States did not include books from Argentina or Brazil, since the topic was "Europe: A Survey" (PHILLPOT in CARRION, 1997: p. 124) In the annotations included in the version published in 1980, mention is made of a Brazilian artist:

The Brazilian Wladimir Díaz-Pino [sic] showed me, during my visit to Brazil in 1978, some of his early books (unfortunately they are now out of print). They are some of the best and most beautiful bookworks I've ever seen. ${ }^{8}$ (Carrión, 1980, p. 66).

Bookworks Revisited was published in 1980 in the Print Collector's Newsletter (CARRION, 1980) and in Second Thoughts (CARRION, 1980). In a more colloquial and speculative, but no less professional rhetoric, Carrión recognizes the intellectual status of the artist visà-vis the publication. In paragraph 17 of Bookworks Revisited, he declared "We are no longer innocent."

13 This statement would be repeated in the structure of Bookworks Revisited Video: Part 1, 1986, which is also associated with the aforementioned lectures. The "Part 1" in the title suggests a continuation that never existed. The video opens with a handwritten phrase: "A selection, both limited in scope and arbitrary, but nevertheless of great significance of bookworks from Ulises Carrión's Other Books and So Archive." His discourse here is didactic and conceptual; he used adapted versions of the channels of communication available to him, namely lectures and video presentations. In Bookworks Revisited (or A selection, both limited...), the description of the book shown at the opening 
of the video does not always appear in the transcripts (in this regard, see the version titled "Other Books" in Quant aux livres/On books, a posthumous collection (CARRION, 1997: p. 190)). The introductory sequence shows the booklet In Alphabetical Order, its pages bearing photos of a small wooden file cabinet (a binder of cards with contacts used here as if it were a book object). Carrión explains the criteria that order the cards he shows: "People I've met. Artists. Non-artists. My best friends, people I love. People I admire. There has been a change in our relationship of late." What bound him to his friends of different nationalities was simple: affection and attachment, qualities demonstrated by his words, gestures and attitudes, as reported by some of his friends and acquaintances. Thanks to this predisposition, as well as to the pragmatic attention he paid to his colleagues, Carrión was useful professionally to the artists and ideas close to him. That is, undoubtedly, what led to "his construction of cultural networks as the key means of artistic activism, including the production of artists' books, mail art and early conceptual videos" (DEBROISE and MEDINA, 2014: p. 30)

\section{Other Jobs Works, Other Circumstances}

Barring a few analyses of the cultural strategies and procedures Carrión used, there are still no major theoretical studies of his art from a critical and formal perspective. Few essays have been written on his production. Carrión forms part of a group of artists engaged with the word or reading, in some cases with literature itself. Like the work of some of those artists, his revolved around the renewal of the linguistic possibilities of the visual arts and, therefore, complexities alien to traditional criticism. Some artists preceded him stylistically in his experiments, others were his contemporaries, but most had direct or indirect contact with him, with Other Books and So as an important point of confluence in those times: Dieter Roth (1930-1998), Robert Filliou (1926-1987), Marcel Broodthaers (1924-1976), Emmett Williams (1925-2007), Ray Johnson (1927-1995), Jochen Gerz (1940), Ian Hamilton Finlay (1925-2006), Jiř̌́ Koláŕ (1914-2002), Endre Tót (1937), Clemente Padín (1939 ), Edgardo Antonio Vigo (1928-1997), Guillermo Deisler (1940-1995), the Noigandres group (a concrete poetry group active in the fifties and sixties ${ }^{10}$ ), the Poem Process movement (an outgrowth of concretism that originated in the late sixties and early seventies but was more closely linked to visual communication ${ }^{11}$ ), among others. There are few stylistic constants in his work from a visual (nonverbal) point of view. His aesthetic identity is enmeshed in the functional expression of his thinking. That identity is, arguably, initially located in the set of operations and movements that built Carrión's cultural persona, that is, his character as at once the subject and agent of an instrumental and structural rearrangement of time, space, and diffusion in art. The most striking aspect of his work may well be its communicative dimension. His interest in the reception of information and its processed return for new consumption oscillates between admiration and irony as it is rendered metaphor in the present and as implicit mood in few key works. As a brief exercise in comparison, let's consider three mild and playful works (he called them "divertimentos" (amusements): the video Gossip, Scandal and Good Manners (1980-81), the $16 \mathrm{~mm}$ film The Death of the Equipment Dealer (1982), and the performance or installation De Diefstal van het Jaar, also from 1982, produced at the Drents Museum in Assen, the Netherlands. 
15 Gossip, Scandal and Good Manners was a project for the De Appel art center. It is organized around the spread of gossip, recording its multiplication and dissemination. The project's conclusions, presented at a formal academic event, hold that "gossip can be used as a formal model for artificial communication chains, which reveals something about its users and the chain itself "(catalog to the XVI Sao Paulo Biennial, 1981, p 79). A 40-minute video shows images of Carrión's final lecture at the University of Amsterdam, which took place on June 25, 1980. The presentation included an edition of interviews with-truth to tell-fake characters, graphics, fragments of opera, etc.

16 In De Diefstal van het Jaar (known in English as The Robbery of the Year and in Spanish as El robo del año), a real diamond was placed on a cushion in the center of a constructed environment. It was left there, waiting to be stolen, for five days. Amsterdam-based Brazilian artist Claudio Goulart (1954-2005), who was one of Gossip...'s characters, was present in disguise, photographing visitors until someone stole it. But to Carrión's chagrin, no crime occurred during the exhibition (it wouldn't happen until a dinner at his residence). ${ }^{12}$

17 The film The Death of the Art Dealer records a performance where Carrion, holding a portable camera, moves sideways, or forward and back, copying the movements of the camera in a low-budget Hollywood film and quickly turning the camera on and off with each cut. The Hollywood film was The Reckless Moment, 1949, directed by Max Ophüls. ${ }^{13}$ The dramatic audio track is the one from the movie playing on television during the performance. The performance takes its name from a phrase that appears in a newspaper headline in a scene from the film on television.

18 Carrión's legacy is currently undergoing reassessment at the initiative, mostly, of his friends and admirers. New academic research has also been performed, bolstering Carrión's value on the symbolic market. Much of the research revolves around two issues. The first is formal, where Carrión's ideas are used to justify works and concepts that he himself rejected (unique books that don't circulate widely and books-objects, understood as modern bookworks, rather than artists' books in the strict sense, that is, as legitimate forms of contemporary art). ${ }^{14}$ The second is contextual, and more interested than the first in the implications of cultural strategies and the network spirit -the latter expressed, above all, in mail art and regional, transnational, and intercontinental collaborations.

19 Brazil is particularly relevant to the current reassessment of Carrión. He delivered lectures at the Universidad Católica de Pernambuco in Recife and at the Pinacoteca del Estado in São Paulo in 1978, and his works were included in some group shows of mail art and related topics during the seventies and eighties. He was a guest artist at the Nucleus I exhibition at the XVI São Paulo Biennial in 1981, under chief curator Walter Zanini (1925-2013) (the mail art exhibition was curated by Julio Plaza (1938-2003)). The Biennial presented his Gossip, Scandal and Good Manners (Fofocas, escândalos e boa educação in Portuguese), and its mail art exhibition featured his ideas for the Erratic Art Mail International System (EAMIS), "an alternative to official post offices." EAMIS "guarantees delivery of the entrusted pieces by any means other than the official post offices," provided the participant leaves a copy or duplicate of the message for the project's archives (that is, the Other Book and So Archive): "By using the EAMIS you support the only alternative to the national bureaucracies and you strengthen the international artists community." Volume II, Catálogo de Arte Postal (Mail Art Catalog) also featured a Portuguese translation of Carrión's Mail Art and the Big Monster. In it, he 
insists that "postal" (mail) is an adjective that qualifies the noun "art," and should not be confused with the Portuguese noun synonymous with cartão-postal (postcard). On those ground, Carrión states: "It has been said that Mail Art is easy, cheap, unpretentious and democratic. All that is rubbish" (XVI BIENAL DE SÃO PAULO, Catálogo de arte postal, 1981, p. 13). He goes on:

Every invitation we receive to participate in a Mail Art project is part of the guerrilla war against the Big Monster. Every Mail Art piece is a weapon thrown at the Monster who is owner of the Castle, who separates us one from one another, all of us. (XVI BIENAL DE SÃO PAULO, Catálogo de arte postal, 1981, p. 14-15).

Despite the admiration he enjoyed in Brazil, his thinking and work would not truly take hold in the country until 2005, at the 5th Mercosur Biennial, curated by Paulo Sergio Duarte. Carrion's work figured prominently in the section entitled "A (re) invention of space." That show included works by Carrión in the form of literature and poetry (sometimes in book form, sometimes not), as well as other projects and postal actions, the videos mentioned before, and twelve editions of the newspaper Ephemera. In the words of Martha Hellion, who selected the works by Carrión in the show, "My selection was diverse to show the different media Ulises used in an artistic language, so to speak, he deployed as part of cultural strategies-the basis for his communication and distribution policy." ${ }^{15}$ The range of materials laid before viewers eloquently confirmed Hellion's argument that Carrión's many works had a common denominator-namely the question of communication and distribution. In the catalog to the 2007 exhibition La era de la discrepancia: arte y cultura visual en México 1968-1997 (The Age of Discrepancy: Art and Visual Culture in Mexico, 1968-1997), Lourdes Morales would reiterate that Carrión's medium was the object (chiefly the book), but also the archive and method (mechanisms for circulation and distribution) (Debroise and Medina, 2014: p. 163 and 167). Carrión formulated, tested out, and critically executed the mediation strategies he observed in the work of his peers.

\section{Closing Considerations}

Returning to the question of the artist's book, it is odd how Carrión's convictions have been coopted by some artists defend creations he would not have wasted his time on, or works that he would have objected to because they did not meet his expectations regarding distribution. When unsuccessful, the sculptural book and the book object (an artistic hybrid that is not really a book, but that participates in the book's symbolic and cultural space, though rarely as an effective means of communication) tend to be conceptually precarious. Both are essentially modern, futuristic, and surrealist. But to both of those media, Carrión preferred the bookwork, the artist's book, an artistic instrument associated with visual and verbal communication and conceptually rooted in contemporary art and the transformation of languages. Though it has fallen into disuse, the term "bookwork" is still necessary. ${ }^{16}$ The term "artist's book," which is widely used internationally today, leaves room for conflicting interpretations.

Articles that, like "The New Art...," are used by defenders of tradition-some of them resentful, others conservative, and still others downright reactionary-to support values of art and of craft that have little or nothing to do with contemporary art and its forms of expression. Indeed, perhaps because of that resentment, intellectuals not overly interested in editions or publications feel authorized to define what does and 
what does not constitute a type of work that goes against their theoretical conception. That leads them to make assertions like "Now that is an artist's book" even as they disdain the communicational intelligence that defines it as such.

As Carrión pointed out in the lecture entitled About Criticism delivered in Boston in 1985, "making artists' books is not primarily dealing with aesthetics but cultural policie." (CARRION, 1997: p. 177). He rarely, if ever, refers to book objects. What he is taking about are bookworks that circulate, that reach their objectives thanks to their intrinsic coherence, their contents, the understanding of their sequential nature, their awareness of the rhythm of reading, their rejection of linear language. And he emphasizes: "When such books finally exist, and when their existence has been acknowledged, then we will have the right to say We have won!"(CARRION, 1983: p. 41).

New questions arise from academic research focused on, among other things, recognizing the influence of Latin American art in the construction of contemporary art. The recovery of an artistic memory obliterated by political regimes that limited civil rights, especially starting in the nineteen-sixties, is a task that has been, in my view, performed by historians, theorists, and critics. More or less recent personal experiences with art history students and with artistic practices point to the need for further study of the historical relationships between networks (prior to the digital world), especially when they engage questions of identity and language. The ties that 
those networks forged must be assessed in a critical and comparative manner. After all, those ties made an art and communication system at once singular and plural.

\section{BIBLIOGRAPHY}

CARRION Ulises, “Bookworks Revisited," Print Collectors Newsletter, New York, 11(1), 1980, p. 6.

CARRION Ulises, “El arte nuevo de hacer libros," Plural, Mexico City, 1975, pp. 33-38.

CARRION Ulises, Quant aux livres/ On books, Geneva, Héros-Limite, 1997.

CARRION Ulises, Second thoughts, Amsterdam, Void Distributors, 1980.

CARRION Ulises, “We have won! Haven't we?,” Flue, New York, III(2), 1983, pp. 39-41.

DEBROISE Olivier, MEDINA Cuauhtémoc (ed.), La era de la discrepancia: Arte y cultura visual en México, 1968-1997, 2.ed., Mexico City, Universidad Nacional Autónoma de México, Turner, 2014.

HELLION Martha (ed), Ulises Carrión: ¿Mundos personales o estrategias culturales?, [Madrid,] Turner, 2003.

HOFFBERG Judith A, “Alternative Art Publishing Conference,” Umbrella, 2(6), 1979.

Llibres d'artista/Artist's books, Barcelona, Metrònom, 1981.

LYONS Joan (ed), Artists' Books: A Critical Anthology and Sourcebook, Rochester, Visual Studies Workshop Press; Layton, Gibbs M. Smith, Inc., Peregrine Smith Books, 1985.

SCHRAENEN Guy, Ulises Carrión: “We have won! Haven't we?,” Amsterdam, Museum Fodor; Bremen, Neues Museum Weserburg, 1992.

SILVEIRA Paulo, “Apontamentos sobre Ulises Carrión," Anais do XXXI Colóquio do Comitê Brasileiro de História da Arte, 2011, Universidade Estadual de Campinas, Campinas, CBHA, 2011, pp. 681-690.

SILVEIRA Paulo, "O livro de artista como documento na metodologia da pesquisa em história da arte," Anais do XXXII Colóquio do Comitê Brasileiro de História da Arte, 2012, Universidade de Brasília, Brasília, CBHA, 2012.

SILVEIRA Paulo, "The space and Time of Ulises" in MA CURATING CONTEMPORARY ART STUDENTS AT THE ROYAL COLLEGE OF ART, Gossip, Scandal and Good Manners: Works by Ulises Carrión, London, Royal College of Art, 2010, pp. 7-9.

XVI BIENAL DE SÃO PAULO (ed), Catálogo de arte postal, São Paulo, Fundação Bienal de São Paulo, 1981, pp. 11-15.

XVI BIENAL DE SÃo PAULO (ed), Catálogo geral, São Paulo, Fundação Bienal de São Paulo, 1981, pp. 78-79.

\section{ENDNOTES}

1. After informal research performed in parallel to his work at the Universidade Federal do Rio Grande do Sul's press, the author, as a master's degree student from 1996 to 1999 and as a PhD 
candidate from 2003 to 2008, began studying the relationship between the artist's book and art history. With the support of the Conselho Nacional de Desenvolvimento Científico e Tecnológico, he is currently working on two studies on this same topic and one on the formation of contemporary art.

2. The term intermidia is used here in the sense proposed by Dick Higgins in his article "Intermidia" in The Somethig Else Newsletter, volume 1, number 1, February 1966.

3. The word "network" is used here in its broadest and enshrined sense in art, just as in "eternal network", an English expression used since the late 1960s by Robert Filliou (1926-1987) and his circle ( because "the network is everlasting"), and consolidated from the launch of his book Teaching and learning as performing arts, London, Occasional Papers, 1970 (republished in facsimile in 2014).

4. His relatively unknown status is evidenced by an experience I had with art students in Mexico in 2012. Martha Hellion had warned me that, even in his country of birth, Carrión was much less known than I might have imagined. That situation was changing, though, thanks to a range of efforts that yielded exhibitions and Spanish editions of texts by Carrión. Those efforts include the publications ¿Mundos personales o estrategias culturales?, 2003, by Turner (accompanying an exhibition); El robo del año, 2013, by Alias press, and the series Archivo Carrión put out by Tumbona press, in conjunction with El arte nuevo de hacer libros, 2012, El arte correo y el gran monstruo, 2013, and Lilia Prado Superestrella y otros chismes, 2014. Carrión was also featured in international exhibitions of varying size, among them the 5th Mercosul Biennial, Porto Alegre; Gossip, Scandal and Good Manners: Works by Ulises Carrión, a retrospective held at The Showroom, London, 2010; Dear Reader Don't Read., at the Museo Nacional Centro de Arte Reina Sofía, Madrid, 2017 (and the Museo JUMEX, Mexico City, 2017); and Documenta 14, Athens and Kassel, 2017. The importance of the exhibition La era de la discrepancia: arte e cultura visual en México 1968-1997, UNAM, 2007, which featured his work, should not be underestimated.

5. Although Carrión had already carried out experimental poetry experiments, living with the collective Beau Geste Press, in England, seems to have been definitive, since it provided his first books, such as Looking for poetry, 1973

6. The book Second Thoughts includes the articles "The New Art of Making Books," "From Bookworks to Mailworks," "Rubber Stamp Theory and Praxis," "Rubber Stamp Art," "Mail Art and the Big Monster," "Table of Mail Art Works," "Personal Worlds of Cultural Strategies?," and "Bookworks Revisited."

7. Prior to the publication of the anthology Quant aux livres / On books, 1997, the article had been published in thirteen different books and newspapers in various languages. It was not until 2011 that its Portuguese translation was published in Brazil in book form. It is easy to find the text on the internet. El arte nuevo de hacer libros (The New Art of Making Books) has been reprinted in Spanish in Tumbona press's Anomalous Collection, 2012, Mexico City.

8. O nome correto é Wlademir Dias-Pino. E na realidade o sobrenome originalmente não era composto, não possuía hífen, que passou a ser usado pelo artista para evitar a separação em referências bibliográficas e outros usos.

The correct name is Wlademir Dias-Pino. And in reality the surname was originally not composed, it did not have a hyphen, which started to be used by the artist to avoid separation in bibliographic references and other uses.

9. It was through Carrion's contact with the intellectual production of the "new avant-gardes" that he recognized the intellectual status of the artist. Those avant-gardes were committed to joining art and communication. The basis for this statement was the greater instrumental commitment of art publications (bookworks and alike) to cultural strategies than to art. See as well "Personal Words or Cultural Strategies?" a text from 1978 for a mail art project published prior to "Bookworks revisited." This text that stemmed from a lecture at the Visual Studies Workshop, Rochester, New York in 1979. Both are reproduced in Second Thoughts (1980). 
10. The early members of the Noigandres group, instigator of concrete poetry in Brazil, were poets Haroldo de Campos (1929-2003), Décio Pignatari (1927-2012), and Augusto de Campos (1931). Ronaldo Azeredo (1937-2006) and José Lino Grünewald (1931-2000) later joined.

11. The Poema Processo movement officially lasted from 1967 (with a manifesto launched the following year) until 1972. Figures active in it included Wlademir Dias-Pino (1927-2018)-an artist featured in the first Exposição Nacional de Arte Concreta in 1956-Moacy Cirne (1943-2014), Álvaro de Sá (1935-2001), Neide Dias de Sá (1940), among others.

12. Mexico City-based Alias press released a small book and an installation, entitled The Robbery of the Year, in mid-2013. Coordinated by Damián Ortega and with the collaboration of Martha Hellion and her archives, the book collected photos taken by Claudio Goulart (1954-2005), a Brazilian artist who lived in the Netherlands.

13. Known in Portugal as $\mathrm{O}$ momento imprudente and in Brazil as Na teia do destino; in Spanish, usually called Almas desnudas (Naked Souls).

14. For key concepts, see Art \& Architecture Thesaurus (AAT), a project of the Getty Research Institute. Its entry for artists' books (books) reads: [...] Books, whether unique items or multiples, made or conceived by artists, including commercial publications (usually in limited editions), as well as unique items formed or arranged by the artist. For texts written by artists for the sake of their informational content, use 'writings.' For artists' books that emphasize the physical book as a work of art rather than the content, use 'bookworks.' For works that look like or incorporate books but do not communicate in the ways characteristic of books, see 'book objects.' Last visited July $\quad 6, \quad 2019 . \quad$ URL: http://www.getty.edu/vow/AATFullDisplay? find $=$ artist\%C2\%B4s+book\&logic=AND\&note=\&english=N\&prev_page=1\&subjectid=300123016.

For reflections on the conceptual problem of the "artist's book" as object or category, and remarks on its place internationally, see SILVEIRA Paulo, A página violada: da ternura à injúria na construção do livro de artista, Porto Alegre, 2001 (Portuguese only).

15. Communication by e-mail with Martha Hellión, May 19, 2013.

16. Returning to Getty's art and architecture thesaurus, the entry for the term "bookworks" reads: "Artists' books that exploit the book form or alter its physical structure as part of the content of the work. Also includes works where emphasis is on the fine crafting of the book. For sculptures that look like or incorporate books but do not communicate in the ways characteristic of books, use 'book objects.'

Last visited July 6, 2019. URL: http://www.getty.edu/vow/AATFullDisplay? find=bookwork\&logic=AND\&note=\&english=N\&prev_page=1\&subjectid=300178842.

\section{ABSTRACTS}

This article discusses the importance of the production and thinking of Mexican artist Ulises Carrión (1941-1989) during the years he spent in Europe. It focuses on his adherence to the network of the Pan-American and European avant-gardes of the seventies; his bookshop Other Books and So; some of his works; and his network strategies and cultural practices. Understanding his thought and his artistic production can shed light on the conceptually problematic "artist's book" category, a term that first arose in the seventies and then resurged in art fairs and exhibitions as well as academic research in the 2010s.

Este artigo comenta a importância das pesquisas sobre a produção e o pensamento do artista mexicano Ulises Carrión (1941-1989) durante sua vida na Europa, destacando a sua convergência para o espírito de rede das vanguardas pan-americanas e europeias dos anos 1970, a importância de sua livraria Other Books and So, alguns de seus trabalhos e suas estratégias ligadas à rede e às 
práticas culturais. Procura-se enfatizar que a compreensão de seu pensamento e de sua produção artística pode possibilitar uma melhor compreensão a respeito das dúvidas conceituais pela designação "livro de artista", designação esta estabelecida como nós a conhecemos nos anos 1970 e nos anos 2010 vivendo momento de ampla e renovada divulgação, de feiras e exposições a pesquisas acadêmicas.

Cet article traite sur la production et la pensée de l'artiste mexicain Ulises Carrión (1941-1989) en particulier pendant sa vie en Europe. Il souligne la convergence de son travail avec les thématiques traitées par le réseau des avant-gardes panaméricaines et européennes des années 1970, ainsi que l'importance de sa librairie Other Books and So. Également sont analysées ici quelques-unes de ses œuvres ainsi que les stratégies liées aux réseaux et aux pratiques culturelles. Nous essayions de souligner que la compréhension de sa pensée et de sa production artistique peut permettre une meilleure compréhension des doutes conceptuels sur la désignation "livre d'artiste", désignation établie dans les années 1970. Ces livres, dans les années 2010, vivront une diffusion renouvelée, avec des foires et expositions, ainsi qu'un intérêt croissant de la recherche universitaire.

\section{INDEX}

Mots-clés: Ulises Carrión. Other Books and So. Art postal. Livre d'artiste. Bookwork.

Keywords: Ulises Carrión. Other Books and So. Mail art, Artist's book, Bookwork.

Palabras claves: Ulises Carrión. Other Books and So. Arte postal. Livro de artista. Livro-obra. 